\title{
Glide Insertion And Dialectal Variation In Kurdish
}

\author{
Aveen Mohammed Hasan, PhD \\ University of Zakho, Kurdistan-Region/Iraq \\ Rebeen Abdulrahman Rasheed, MA. \\ University of Duhok, Kurdistan-Region/Iraq
}

doi: 10.19044/esj.2016.v12n14p289 URL:http://dx.doi.org/10.19044/esj.2016.v12n14p289

\begin{abstract}
One of the strategies used as a hiatus resolution is glide insertion. Previous Kurdish phonological works involve only a description of glide insertion in one dialect neglecting the segmental context. This study provides an analysis of glide insertion in word-medial vowel clusters in Kurdish and it is the first attempt to analyse the effects of dialect and segmental context. The speech material includes a set of words consisting of a stem plus a suffix with different vowel sequences at their boundaries. It is produced by four native speakers from four Kurdish speaking areas. The data analysis involves word transcription, their segmentation and the comparison of vowel sequences within and across the subdialects. The results indicate that glide insertion is not the only strategy used as word medial hiatus resolution, but it depends on the segmental context and dialect. Generally, the vowel hiatus is resolved by / $\mathrm{j} /$ insertion. Vowel deletion is also used obligatorily in some segmental contexts when the second vowel in a sequence is / $\mathrm{i} /$ and also when there are identical vowels in a sequences. Dialectal variations are observed in some vowel sequences in which / $\mathrm{j} /$ insertion and vowel deletion both are used and when the first vowels in the sequence are the high back vowels in that $/ \mathrm{j} /$ and $/ \mathrm{w} /$ insertions are used. The findings suggests that $/ \mathrm{j} /$ insertion is the default strategy to resolve word-medial vowel clusters in Kurdish, the insertion of $/ \mathrm{w} /$ or vowel deletion are other strategies which are limited to some dialects and vowel sequences.
\end{abstract}

Keywords: Glide insertion, hiatus resolution, dialectal variation, segmental context, vowel deletion

\section{Introduction}

Glide insertion (GI) is one of the phonological rules that involve consonantal insertion, i.e. a process in which a consonant which is not present underlyingly appear on the phonetic surface (Zygis, 2010). In this 
process, a glide sound, /j/ or /w/, is inserted between two adjacent vowels. Both $/ \mathrm{j} /$ and $/ \mathrm{w} /$ are considered glides in the phonemic system. They are mentally represented as neither vowels nor consonants, have their own constriction degree, and have two designated articulators: [Coronal] and [Dorsal] in the case of $/ \mathrm{j} /$, and [Labial] and [Dorsal] in the case of $/ \mathrm{w} /$ (Nevins and Chitoran, 2008). Glides differ from the vowels in the constriction degree (vowels have less constriction, while glides have greater constriction) and the property of vocalic (syllabic) (they do not occur at syllable-nuclear position) (Ibid).

As other types of insertion, GI has the functions of avoiding vowel hiatus and militating against onsetless syllables (Zygiz, 2009). Usually languages do not tolerate vowel clusters: two vowels occurring consecuentively. When two vowels occur together, languages adopt different strategies to resolve this hiatus. One of these strategies is GI in that a glide, /j/ or /w/ is inserted to break the vowel sequence.

Uffman (2007) claimed that in intervocalic contexts, glides are preferred because they are the most sonorous segments and very similar to vowels, i.e. they have the same featural make up as vowels except for syllabicity. In both place and manner of articulation, glides are maximally similar to their vocalic context in that they are minimally contrastive with their environment.

As for the other function of GI, there is a cross-linguistic preference for syllables with onsets which is expressed by the onset constraint: syllables must have onsets (Uffmann, 2007; Molczanow, 2008; Blevins, 2008). Thus GI is used as a strategy to satisfy this onset constraint. In other words, the inserted glide acts as the onset of the second vowel in a vowel sequence.

Actually, there are no general classifications of the types of GI in the literature. Booij (1996) distinguished homorganic GI in Dutch in which the quality of the glide is determined by the first of two adjacent vowels: $/ \mathrm{j} / \mathrm{is}$ inserted after front vowels (1a) and /w/ after high back vowels (1b).

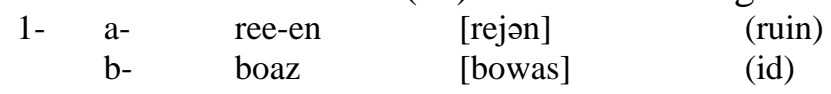

Another type of GI is identified in which one type of glide in inserted regardless of the quality of the adjacent vowels. This type will be distinguished as non-homorganic GI. In Uyghur (Vaux, 2001), for example, GI is not homorganic because [j] is inserted regardless of the quality of the two neighbouring vowels, as in:
2- $\quad \mathrm{a}-$
oqu $+\mathrm{Al}-$
[oquyal-]
(to be able to read)
b- $\quad$ iSlä+Al-
[iSläyäl-]
(to be able to work) (Hahn, 1991 cited in Vaux, 2001:5)

In Guajiro (Vaux, 2001), an Abajero dialect also, non-homorganic GI can be identified in that [w] is inserted regardless of the vowel quality, as in: 
3- a- atpanaa+ee+chi

b- $\quad$ ke+kii+ee+shi

atpanaa[w]eechi

(it will be rabbit)

(he wants to have a (good)

head) (Vaux, 2001: 8)

GI occurs in a large number of languages such as Polish (Rubach, 1984), Dutch (Booij, 1996), Japanese (Kawahara, 2002), Sinhala and Shona (Zygis, 2010), Persian (Dehghan, 2012) and American English (Davidson \& Erker, 2014), to mention but a few. In all theses languages, GI is the most frequent phonological process whose context is well-defined: [j] is inserted in the context of preceding or following high vowels and $[\mathrm{w}]$ in the context of preceding or following non-high vowel and it has the functions of avoiding vowel hiatus and militating against onsetless syllables.

Zygis (2009), in his survey of phonological processes on 400 languages, showed that phonologically such process involves an insertion of segments which incur features via spreading from the neighbouring vowels, whereas phonetically no segment is inserted, i.e. it is rather a percept of formant transition of neighbouring vowels which makes the perceptual indication of a new emerging sound. In order to gain more insights into the topic, he conducted a perceptual study which involved the manipulation of transition length in the item [ia]. The transition between [i] and [a] was lengthened from 50 to $230 \mathrm{~ms}$ in $30 \mathrm{~ms}$ steps so that a 7-step continuum was created. The total duration of the item and the duration of [a] were made constant. The files were played twice from a laptop via headphones to ten native speakers of German, three native speakers of Polish and three of English. The subjects were asked to write down what they hear. [j] was heard in all answers at various transition lengths.

Staroverov (2014), on his part, proposed that in GI no phonological insertion operates, but the addition of the consonant in the output results from a mapping where the input segment corresponds to two output segments. For example, in the /e+a/ vowel sequence in the input, /e/ splits to /ej/ in the output. The major consequence of his theory is that the epenthetic consonants are affected by faithfulness, i.e. preserving input features. In other words, in any input-output mapping, epenthetic segments will seek to be as faithful as possible to their input correspondents. Thus, /e/ in the above examples, splits to /ej/ not /ew/ because /j/ is more faithful to /e/ than /w/.

Finally, it is important to distinguish GI from glide formation that is found in a number of languages to avoid vowel hiatus as well. In Russian (Molczanow, 2008), for example, gliding of the high front vowel is used as a hiatus resolution strategy in $\# \mathrm{iV}, \mathrm{Vi} \#$ and $\mathrm{ViV}$ strings. So, for instance, the underlying sequence /ia/ (ja 'I') is realised as [ja], constituting a well-formed syllable with an onset filled with the glide. Molczanow states that the change of a vowel into a glide entails the deletion of an underlying mora and it is 
better to delete a mora than to have an onsetless syllable (according to the markedness constraint: syllables must have onsets).

\section{Kurdish Language}

Kurdish belongs to the Indo-European family of languages. It is a member of the north-western subgroups of Iranian languages which are subdivisions of the Indo-Iranic branch of this largest family of languages in the world. The Kurdish speech area is divided among five neighbouring countries of Turkey, Iran, Iraq, Syria and Russia. Kurdish is divided into a number of dialects. According to the Kurdish Academy of Language (1992), Kurdish dialects are classified into: Northern Kurdish dialects (NK), Middle Kurdish (MK), Southern Kurdish (SK), Dmili or Zaza and Hawrami.

Although there are a number of studies on the Kurdish phonemic system (Marif, 1976; Ways, 1984; McCarus, 1987; Thackston, 2006; Mohammed, 2009; to mention but a few), no general and unified classification of the phonemic inventory exists to date. Scholars disagree on the number of phonemes especially with regard to their phonological status. Based on Hasan (2012), the following tables summarises the vowels (table 1) and consonants (table 2) of Kurdish. The MK (Middle Kurmanji) and NK (Northern Kurmanji) beside the phoneme symbol indicate that it is just found in that variety.

Table 1: Kurdish vowel phonemes

\begin{tabular}{|c|c|c|c|}
\hline & Front & Central & Back \\
\hline Close & i: & & $\mathrm{u}$ \\
& $\mathrm{i}$ & & $\mathrm{o}$ \\
\hline Mid-close & $\mathrm{e}:$ & & $\mathrm{a}:$ \\
\hline Mid-open & $\mathrm{a}$ & & \\
\hline Open & & & \\
\hline
\end{tabular}

Table 2: Kurdish consonant phonemes

\begin{tabular}{|c|c|c|c|c|c|c|c|c|c|}
\hline & 离 & 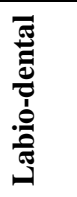 & $\begin{array}{l}\frac{\grave{\pi}}{0} \\
\frac{0}{2}\end{array}$ & 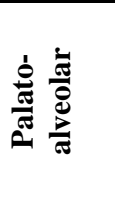 & 吾 & $\frac{\pi}{\partial}$ & 흘 & 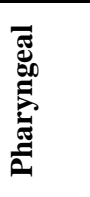 & $\begin{array}{l}\text { 좋 } \\
\text { 훈 }\end{array}$ \\
\hline Fricatives & & $\mathrm{f} \mathrm{v}$ & $\mathrm{s} \quad \mathrm{z}$ & 3 & & $\mathrm{x} \mathrm{\gamma}$ & & $\hbar \varsigma$ & $\mathrm{h}$ \\
\hline Plosives & $\begin{array}{c}\mathrm{p} \\
\mathrm{p}^{\mathrm{h}}(\mathrm{NK}) \\
\mathrm{b} \\
\end{array}$ & & 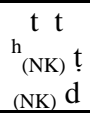 & & & $\begin{array}{c}\mathrm{k} \\
\mathrm{k}^{\mathrm{h}_{(\mathrm{NK})}} \\
\mathrm{g} \\
\end{array}$ & $q$ & & \\
\hline Affricates & & & & $\begin{array}{c}\left.\mathrm{tg}^{\mathrm{f}} \mathrm{f}^{\mathrm{h}} \mathrm{NK}\right) \\
\mathrm{d}\end{array}$ & & & & & \\
\hline Nasals & $\mathrm{m}$ & & $\mathrm{n}$ & & & & & & \\
\hline Flap & & & $\mathrm{r}$ & & & & & & \\
\hline Trill & & & $\mathrm{r}$ & & & & & & \\
\hline Lateral & & & $1 \mathrm{t}_{(\mathrm{MK})}$ & & & & & & \\
\hline Approximants & $\mathrm{w}$ & & & & i & & & & \\
\hline
\end{tabular}


Concerning syllable structure, it is claimed that one-vowel syllables do not exist in Kurdish (Marif, 1976) because vowel-syllables are usually preceded by a glottal stop / $/$. Furthermore, concerning the distribution of vowels and consonants in the syllable, any vowel may appear in the nucleus of the syllable and any consonant can appear in the onset and coda parts except / $/$ / which does not occur in the coda (Hasan, 2009). As for phonotactics, Kurdish permits consonant clusters-two or more consonants coming together in one sequence without an intervening vowel, but it does not allow more than two consecutive consonants in initial and final positions of the syllable.

\section{Previous works in GI in Kurdish}

GI is not analysed systematically in previous works in Kurdish phonology. It is only described in the literature on morphology that by adding a vowel-initial suffix to a vowel-final stem, an $[\mathrm{y}](=/ \mathrm{j} / \mathrm{IPA})$ is inserted (Fattah, 1980; Thackston, 2006; Yasin, 2006). For example, the indefinite suffix has two forms: $<e k>$ is added to consonant-final words and $<y e k>$ is added to vowel-final words, as illustrated in 4a and 4b. Throughout the paper, the examples are written using the Latin Kurmanji writing system $^{72}$, their transcription is given using IPA (revised version 93) in slashes and their meanings in English are given in rounded brackets.

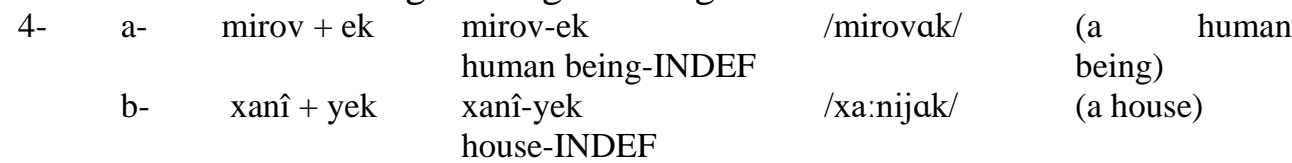

Similar to previously mentioned languages, Hasan (2012) also claims that in NK Kurdish, GI is applied to avoid vowel clusters and satisfy the onset constraint. She identifies it as a phonological process that occurs between two adjacent vowels word medially at root-suffix boundary and according to onset requirements the inserted glide acts as the onset of the vowel-initial suffix (or the initial syllable of polysyllabic suffixes).

She adds that this rule is obligatory and it is applied whenever a vowel-initial suffix is added to a stem in which the final vowel is [î, u, or o], as illustrated in the following examples in 5a-d:

\footnotetext{
${ }^{72}$ Kurdish is written in different writing systems, namely modified Arabic, Latin Kurmanji and Cyrillic. Even in the symbols within these systems differ between the scholars and they do not contain symbols for a lot of sounds which are also identified in Kurdish. This study adopts the Latin Kurmanji writing system (Kurdish Academy of Language, 1992) because it is very close to the English writing system and because it is very close to the IPA phonetic transcription system used. Some letters which give different sound symbols include [a] for $/ \mathrm{a}: /$, [c] for $/ \mathrm{d} z /$, [ç] for $/ \mathrm{t} /$, [e] for $/ \mathrm{a} /$, [ê] for $/ \mathrm{e}: /$, [ï] for $/ \mathrm{h} /$, [î] for $/ \mathrm{i}: /$, [j] for $/ 3 /$, [ l'] for $/ \mathrm{t} /$,

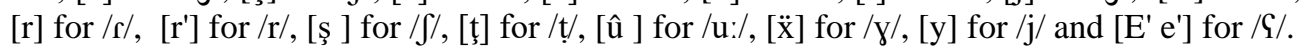




$$
\begin{aligned}
& \text { 5- a- gundî + êt gundî-y-êt } \quad \text { /gundije:t/ } \quad \text { (villagers of...) } \\
& \text { b- rêvî + ê pîr rêvî-y-ê pîr /re:vije: pi:r/ (the old fox) } \\
& \text { c- xwesu + a xwesu-y-a min /xwasuja: min/ (my mother-in-law) } \\
& \min \\
& \text { d- zaro + ê min zaro-y-ê min /za:roje: min/ (my child) }
\end{aligned}
$$

Additionally, she states that when the final syllable of the stem ends in [a, e, or ê] followed by a vowel-initial suffix, either a glide is inserted or the vowel of the stem is deleted and the remaining onset consonant acts as the onset of the vowel-initial suffix (6a-e).

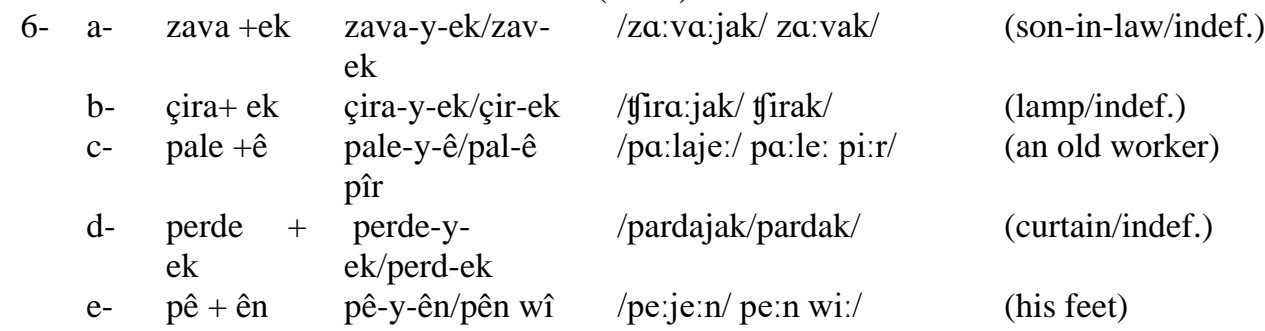

Besides, she claims that GI in NK is not homorganic in that $/ \mathrm{j} /$ is inserted regardless of the quality of the first vowel, although she does not carry out any experiments to show the effect of segmental context on GI. However, she adds that $/ \mathrm{w} /$ is also possible in some subdialects when the first vowel is $/ \mathrm{o} /$ or $/ \mathrm{u} /$, but she does not identify exactly which subdialects. For instance:

$$
\begin{aligned}
& \text { 7- a- du + em du-y-em/du-w-em /dujam/duwam/ (the second) } \\
& \text { b- sto+ê sto-y-ê/sto-w-ê /stoje:/ stowe:/ (neck of ...) }
\end{aligned}
$$

Hasan (2012) concludes that the GI rule in NK Kurdish is a domain span rule which is applied at root-suffix boundary and she identifies the phonological word (PW) as the rule-application domain.

The previous works on GI have described this process in one dialect (for example, Thackston, 2006 and Hasan, 2012 for NK Kurdish), but no studies have described GI across a number of dialects to observe whether there are any dialectal variations. Additionally, the effects of segmental context on GI have not been investigated yet. This study is the first attempt to analyse the effects of dialect and segmental context on GI.

\section{Methodology Speech material}

To achieve the purpose of the study, a set of words are formed by the combination of stems and suffixes which involve different vowel-vowel sequences at the root-suffix boundary. The designed words include roots ending in the vowel sounds /a: a, e, o, u, i:, i/, which represent the seven vowel sounds of Kurdish (Hasan, 2012) and the vowel /u:/ which has some debates about its phonemic status in the literature, plus suffixes beginning with the same vowel sounds. Words ending in /i/ cannot be found and 
suffixes beginning with $/ \mathrm{u}$, o and $\mathrm{u}: /$ do not exist. Additionally, vowel sequences $/ \mathrm{e} /+/ \mathrm{i}$ : and $\mathrm{i} /$ and $/ \mathrm{u} /+\mathrm{i}$ : and $\mathrm{i} /$ are not examined due to the unavailability of data. Thus, the total number of vowel sequences that are examined are 31. Table 3 illustrates the data design of the study.

Table 3: Method of data design

\begin{tabular}{|c|c|}
\hline Stems & Suffixes \\
\hline Ending in /a:/: derya (sea), çiya (mountain) & Beginning with /e/: [ên] plural possessive \\
\cline { 2 - 2 } Ending in /a/: perde (curtain) & Beginning with /a/: [ek] indefinite singular \\
\cline { 2 - 2 } Ending in /e/: pê (foot) & Beginning with /a:/: [a] singular feminine \\
Ending in /o/: çeqo (knife) & possessive \\
Ending in /u/: saku (jacket), gezu (nut) & \\
Ending in /i:/: kanî (spring) & \\
Ending in /u:/: rû (cheek) & Beginning with /i:/: [în] first person plural \\
\hline Ending in /a:/: rawest (stay) & personal pronoun \\
Ending in /a/: bike (do it) & personal pronoun \\
Ending in /o/: bixo (eat) & \\
Ending in /i:/: krî (buy) & Beginning with /i/: [in] second person plural \\
Ending in /u:/: çû (go) & \\
\hline
\end{tabular}

\section{Speakers}

The study is based on recordings of the designed words as produced by four Kurdish native speakers (2 males and 2 females) from four subdialects, namely, Duhok, Qamishlo and Diyarbekir from NK and Hewler from MK. All the speakers are recruited in Duhok because they either live, study or work there. The speakers are educated and they speak another language in addition to Kurdish. However, they use these languages occasionally. So we can assure that there is no influence of the second language on their native language because of its rare use. Furthermore, none of the speakers reported any speech or hearing problems and all of them were naïve as to the purpose of the study. Additionally, none of them had been recorded before. Their participation was voluntary and did not imply any kind of compensation.

\section{Procedures of data collection}

The recordings took place in Duhok. The speakers had been recorded individually. Each speaker was asked to produce the word that was formed by a given stem and a suffix. The speaker's production of the formed word was recorded. The recording sessions lasted for four weeks.

The data designed were written in Arabic and Latin alphabet because speakers who were from Duhok and Hewler knew the Arabic alphabet, but those who were from Qamishlo and Diyarbakir knew the Latin Kurmanji alphabet. The recordings were carried out using a computer, microphone and PRAAT program (Boersma \& Weenink, 2009). 


\section{Data analysis}

The data was transcribed using the Latin Kurmanji writing system. Then it was segmented manually using PRAAT. The stem of the word and the suffix were separated and the inserted glide was indicated. Figure 1 shows the segmentation of an example from the data.

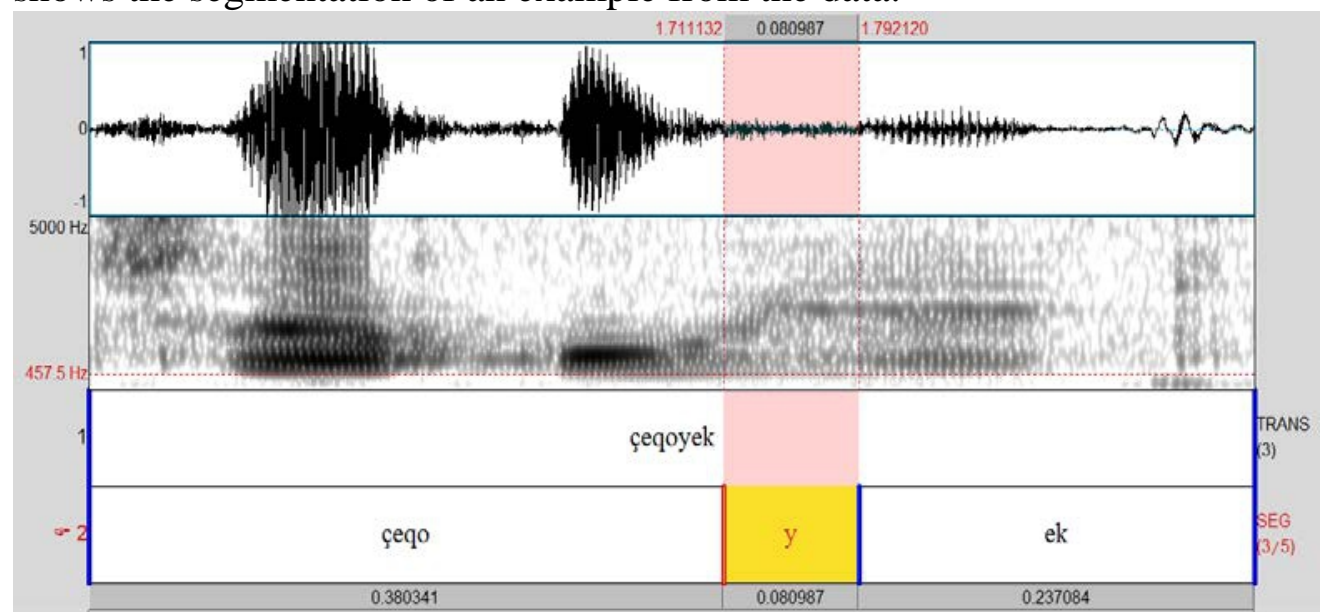

Figure 1: A PRAAT window showing the segmenting of the word <çeqoyek> (a knife) as produced by a female speaker from Duhok dialect

The other part of data analysis involves making comparisons. Each sound sequence was contrasted with other sound sequences in two ways. On one hand, a specific sound sequence produced by a specific speaker was compared with other sound sequences produced by other speakers in one dialect. This comparison helped to provide intra-dialect information about GI. On the other hand, a specific sound sequence was compared with similar sound sequences produced by speakers from other dialects. This gave information about inter-dialect variations.

\section{Results}

The results show that the vowel clusters at root-suffix boundary are resolved by different strategies depending on the vowel sequence and dialect. They are usually resolved by /j/ insertion, while / $/ \mathrm{w} /$ insertion and vowel deletion are also used depending on the dialect and vowel sequence, as well as some speaker variations are also observed.

\section{Hiatus resolution by / $\mathbf{j}$ / insertion}

In the following vowel sequences, the vowel clusters are resolved by $/ \mathrm{j} /$ insertion in all dialects by all speakers. The inserted $/ \mathrm{j} /$ acts as the onset of the vowel initial suffix. 
8-

$/ \mathrm{a}: /+/ \mathrm{a}: /$

9- $\quad / \mathrm{a}: /+/ \mathrm{a} /$

10- /a: $/+/ \mathrm{e}: /$

11- / $\mathrm{a}: /+/ \mathrm{i}: /$

12- / $/ \mathrm{a} /+\mathrm{i}: /$

13- /e: $/+/ \mathrm{a}: /$

14- / e: $/+/ \mathrm{a} /$

15- $\quad / \mathrm{e}: /+/ \mathrm{e}: /$

16- $\quad / o /+/ a: /$

$17-\quad / 0 /+/ \mathrm{a} /$

18- $/ \mathrm{o} /+/ \mathrm{e}: /$

19- $/ \mathrm{o} /+/ \mathrm{i}: /$

20- / i: $/+/ \mathrm{a}: /$

$21-\quad / \mathrm{i}: /+/ \mathrm{a} /$

$22-\quad / \mathrm{i}: /+/ \mathrm{e}: /$

23- /u: $/+/ \mathrm{i}: /$ derya + a/an $\rightarrow$ deryaya / deryayan

çiya + an $\rightarrow$ çiyayan

derya + ek $\rightarrow$ deryayek

çiya + ek $\rightarrow$ çiyayek

derya + ên $\rightarrow$ deryayên

çiya + ê/ên $\rightarrow$ çiyayê / çiyayên

rawesta + în $\rightarrow$ rawestayîn

bike + în $\rightarrow$ bikeyîn

pê + an $\rightarrow$ pêyan

pê + ek $\rightarrow$ pêyek

pê + ê/ên $\rightarrow$ pêyê / pêyên

çeqo + a/an $\rightarrow$ çeqoya / çeqoyan

çeqo + ek $\rightarrow$ çeqoyek

çeqo + ên $\rightarrow$ çeqoyên

bixo + în $\rightarrow$ bixoyîn

kanî + a/an $\rightarrow$ kanîya / kanîyan

kanî + ek $\rightarrow$ kanîyek

kanî + ên $\rightarrow$ kanîyên

çû + în $\rightarrow$ çûyîn

Consider the following figures which illustrate the production of <çûyîn> in the four sub-dialects.

a- Diyarbakir

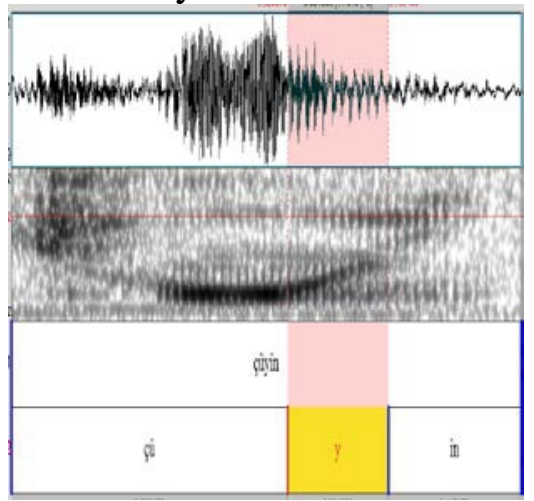

c- Qamshlo

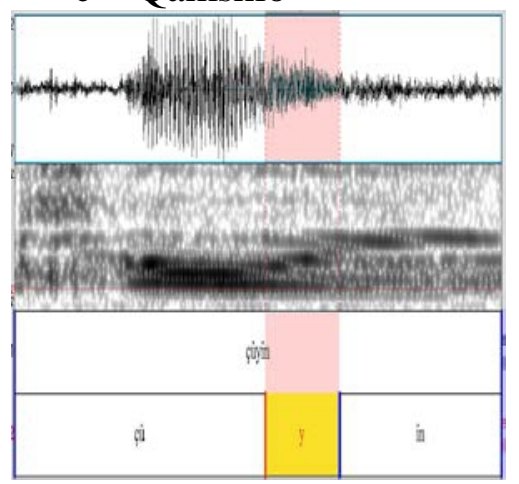

Figure 2: Spectrums of the word <çûyîn> as produced by speakers from Diarbakir, Duhok, Qamshlo and Hewler b- Duhok

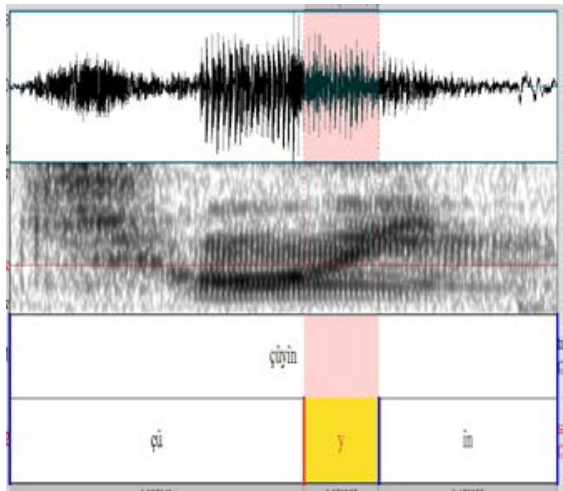

d- Hewler

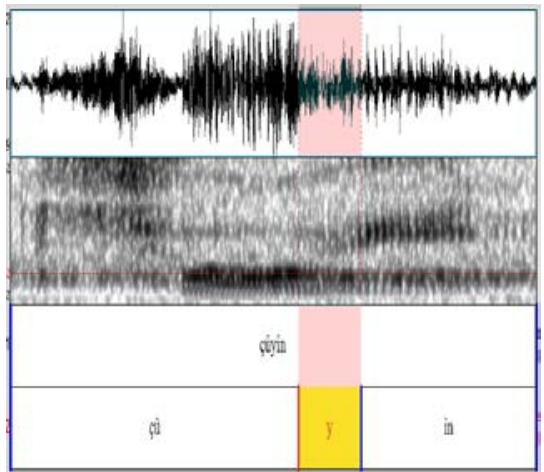


The sequences indicate that $/ \mathrm{j} /$ is inserted regardless of the vowel quality, i.e. it is inserted after front (a, i:, e:) and back vowels (a:, o, u:) as well. This result confirms Hasan's (2012) claim that GI is non-homorganic in Kurdish.

\section{Hiatus resolution by vowel deletion}

Vowel deletion is another strategy used to resolve word-medial vowel hiatus. It is observed when the second vowel in sequence is $/ \mathrm{i} /$. When the suffix <-in> which begins with /i/ is added to stems ending in /a:, a, o, i:, or $\mathrm{u}: /$, vowel deletion occurs in that $/ \mathrm{i} /$ of the suffix is deleted to avoid vowel cluster in all dialects. When /i/ is deleted, resyllabification triggers in that the remaining coda consonant is resyllabified to form a coda to the preceding syllable. For example,
24- / a: $/+/ \mathrm{i} /$
rawesta + in $\rightarrow$ ra.we.stan
$25-\quad / \mathrm{a} /+/ \mathrm{i} /$
bike + in $\rightarrow$ bi.ken
26- $\quad / 0 /+/ \mathrm{i} /$
bixo + in $\rightarrow$ bi.xon
$27-\quad / \mathrm{i}: /+/ \mathrm{i} /$
krî + in $\rightarrow$ krîn
28- $\quad / \mathrm{u}: /+/ \mathrm{i} /$
çû + in $\rightarrow$ çûn

The following figures illustrate the production of the word $<k r i ̂ n>$ as produced by the speakers of the four dialects.

a- Diarbakir

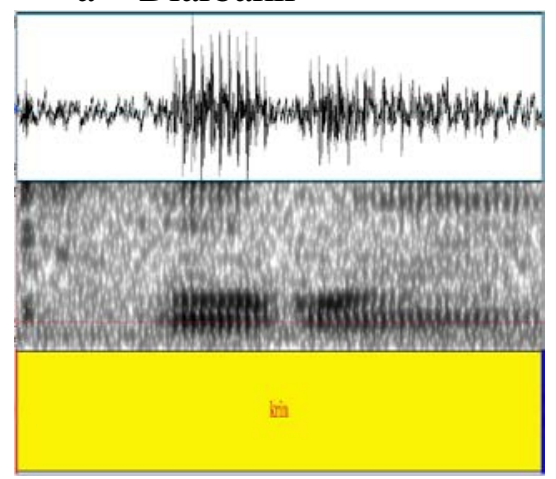

c- Qamshlo

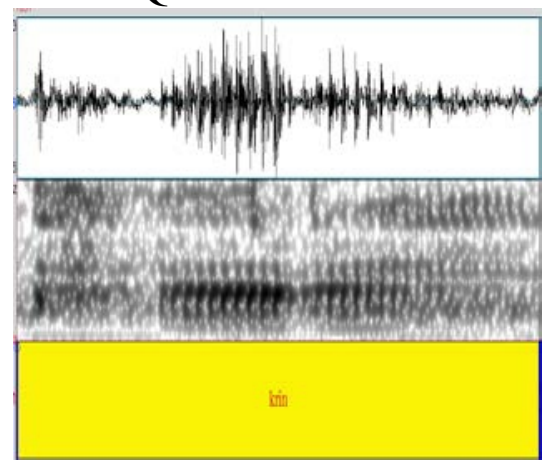

b- Duhok

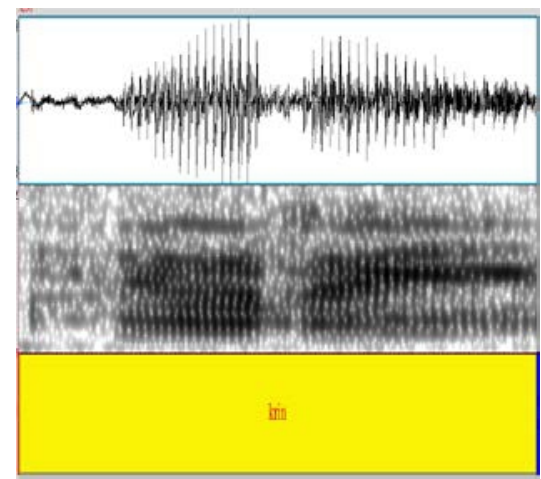

d- Hewler

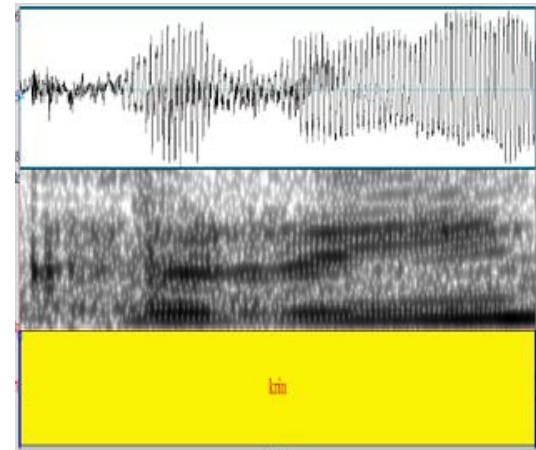

Figure 3: Spectrums of the word <krîn $>$ as produced by speakers from Diyarbakir, Duhok, Qamshlo and Hewler 
/i/ deletion has been previously described by Hasan (2012). She states that /i/ in unstressed CV syllables is deleted in most occurrences (however, it is realised in careful slow speech of some speakers). She adds when $/ \mathrm{i} / \mathrm{is}$ elided an obligatory resyllabification occurs in that the remaining consonant syllabifies to form a cluster with the onset of the following syllable. She claims that this rule occurs within the PW-domain and it is applied between a prefix and a stem as in the case of the progressive prefix <di $>$ in 29a, in mono-morphemic words as in 29b and between monosyllabic prepositions which have the structure $\mathrm{Ci}$, such as $<j i>$ (from), $<b i>$ (by), $<l i>$ (in) and the following noun as in 29c:

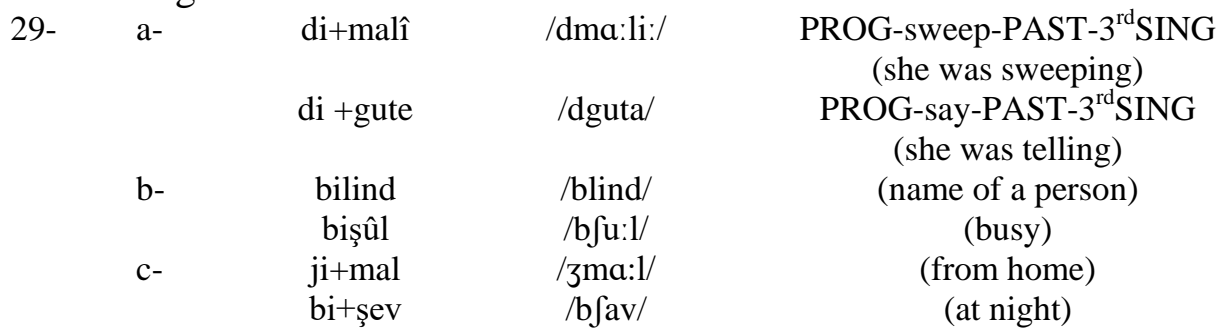

The study here shows that /i/ deletion has another function which is resolving vowel clusters. It occurs when the second vowel in a sequence is /i/. When /i/ is deleted, the remaining coda consonant is resyllabified to form a coda to the preceding syllable.

Another case in which vowel deletion is used to avoid vowel cluster is when there is a sequence of identical vowels. In the sequence $/ \mathrm{i}: /+\mathrm{i}: /$, no glide is inserted and the first / $\mathrm{i}$ :/ is deleted to resolve the vowel cluster in all dialects.

30- krî + în $\rightarrow$ krîn

vowel deletion has been described for French (Harris, 2011) and Dutch (Booij, 1996) which occurs to avoid vowel sequences. In French, when the masculine [le] or the feminine [la] determiners precede a vowelinitial noun, the vowel of the determiner is elided and the remaining consonant is syllabified as the onset of the following vowel-initial syllable, as in:

31-
a- le ami
lami
(the friend (m.))
b- la amie
lamie
(the friend (f.))

In Dutch, vowel deletion is found in host+enclitic constructions. When the vowel is elided, obligatory resyllabification occurs and in the case of host+enclitic the enclitic is integrated with the preceding host in one PW, e.g. (from Booij, 1996: 226):
32-
zette het
(put it)
/zetə ət/
[zetət]

To sum up, vowel deletion is another strategy used to avoid vowel sequences that occur word-medially in Kurdish. However, this strategy occurs in restricted segmental contexts, that is, when the second vowel in a sequence is / $\mathrm{i} /$ and in identical vowel sequences. 


\section{Hiatus resolution by $/ \mathbf{j} /$ insertion and vowel deletion}

When a sequence of /a/ and /a:, a or e:/ occurs, /j/ insertion and vowel deletion are used to resolve the cluster depending on the dialect. In Hewler, $/ \mathrm{j} /$ is inserted in these vowel sequences by all speakers, as it is found in the following examples and illustrated in the spectrums in figure 4:
33- $\quad / a /+/ a: /$
34- $\quad / \mathrm{a} /+/ \mathrm{a} /$
35- $\quad / \mathrm{a} /+/ \mathrm{e}: /$

perde + an $\rightarrow$ perdeyan

perde + ek $\rightarrow$ perdeyek

perde + ên/êk $\rightarrow$ perdeyên / perdeyêk
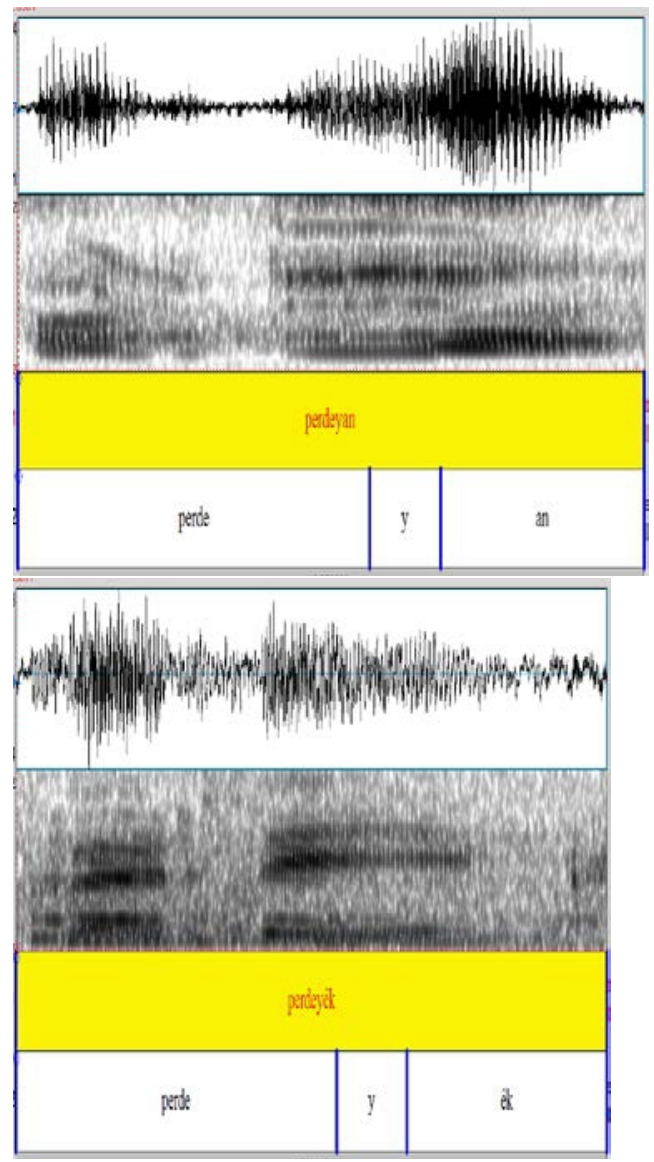

Figure 4: Spectrums of the words < perdeyan>, <perdeyek> and < perdeyêk $>$ as produced by speakers from Hewler dialect

In Qamshlo, the cluster is not resolved by GI, but by vowel deletion. In this case, /a/ of the final syllable of the stem is deleted and the remaining onset consonant resyllabifies as the onset of the vowel-initial suffix, as illustrated in the following examples and their spectrums in figure 5:

36- perde $+\mathrm{a} \rightarrow$ per.da

37- perde + ek $\rightarrow$ per.dek

38- perde + ên $\rightarrow$ per.dên 

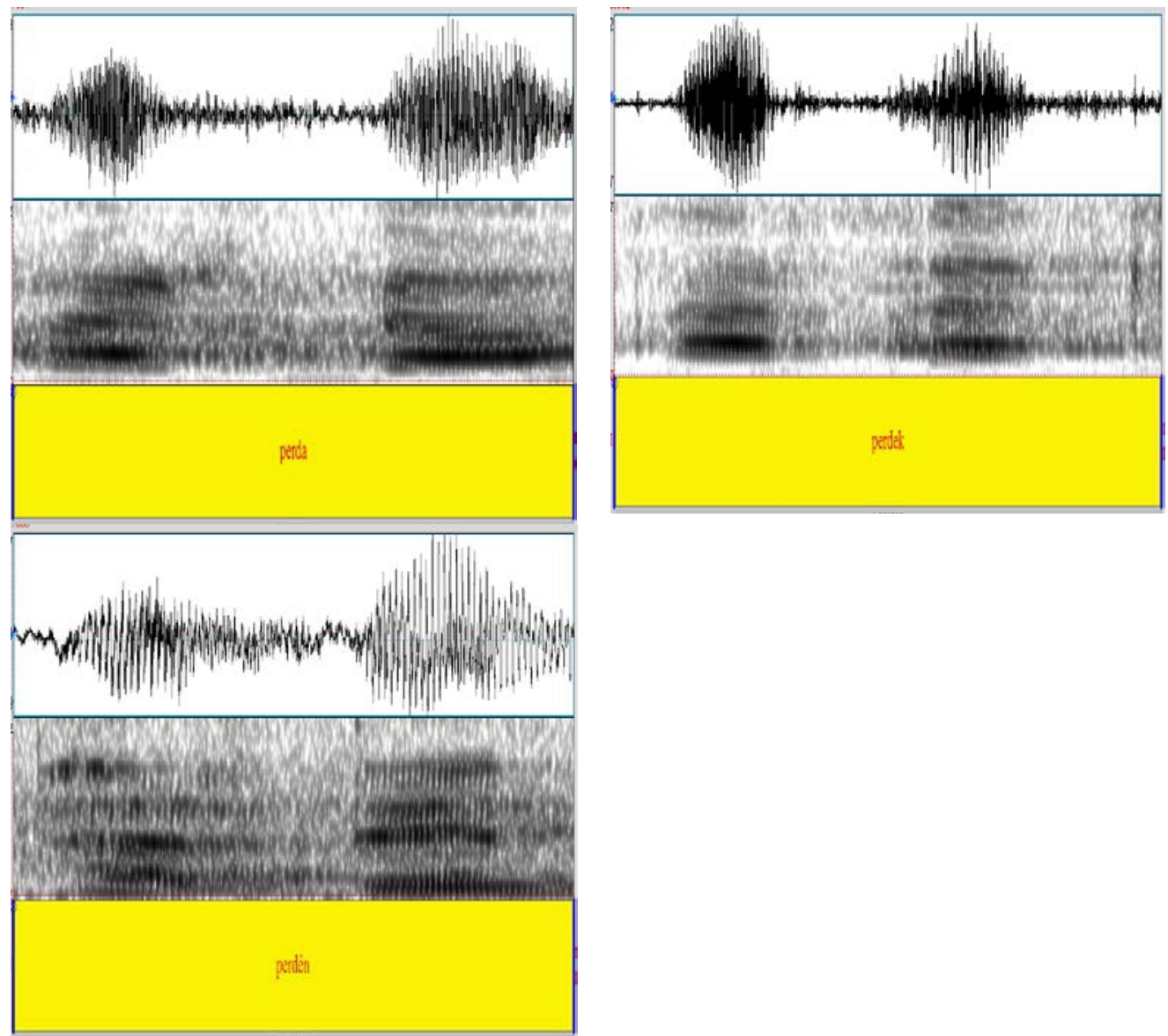

Figure 5: Spectrums of the words $<$ perda $>$, < perdek $>$ and $<$ perdên $>$ as produced by speakers from Qamshlo dialect

In Diyarbaker and Duhok, in the sequence $/ \mathrm{a} /+/ \mathrm{e}: /$, the $/ \mathrm{a} /$ of the stem is deleted <perdên $>$. In the sequence of $/ a /+/ a / /$, all the speakers of Diyarbaker deleted the $/ \mathrm{a} /$ of the stem $<$ perdek $>$, while the speakers of Duhok solved the cluster by the insertion of $/ \mathrm{j} /$, <perdeyek $>$. In the sequence of $/ \mathrm{a} /+/ \mathrm{a}: /$, in both dialects the cluster is solved by either the deletion of the $/ \mathrm{a} /$ of the stem $<$ perda $>$ or by $/ \mathrm{j} /$ insertion $<$ perdeya $>$. Figure 6 shows the variations in the production of the structure $<$ perde $+a>$ in Diarbakir and Duhok. 
a- Diarbakir

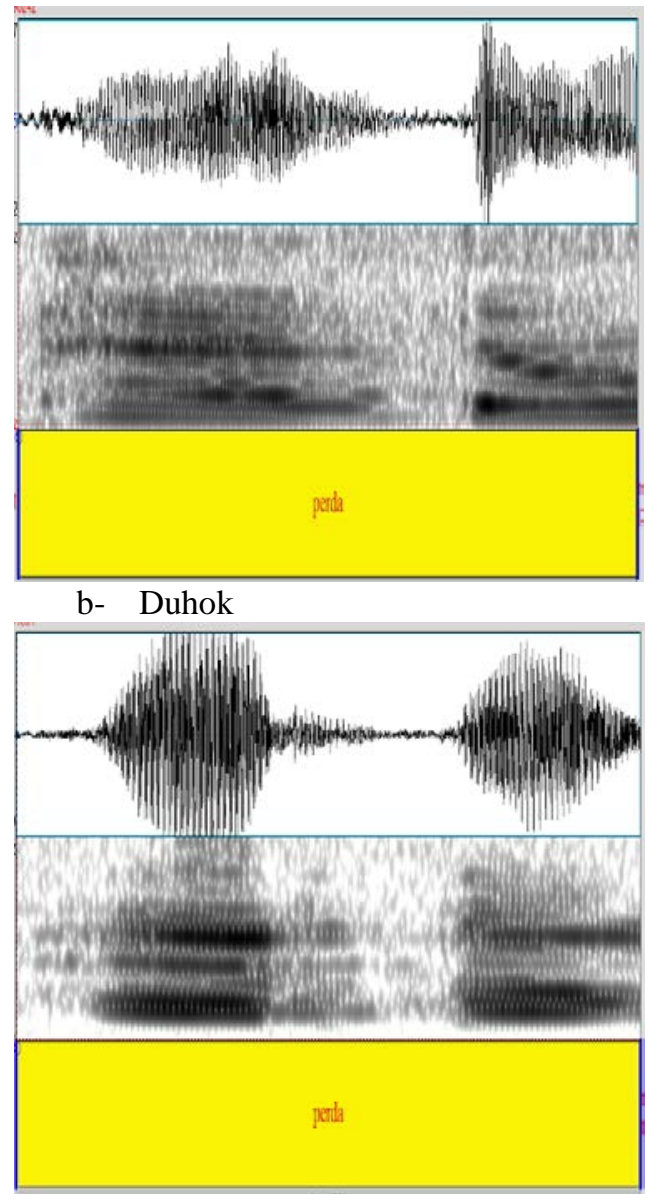

Figure 6: Spectrums of the structure $<$ perde $+a>$ as produced by different speakers from: a)
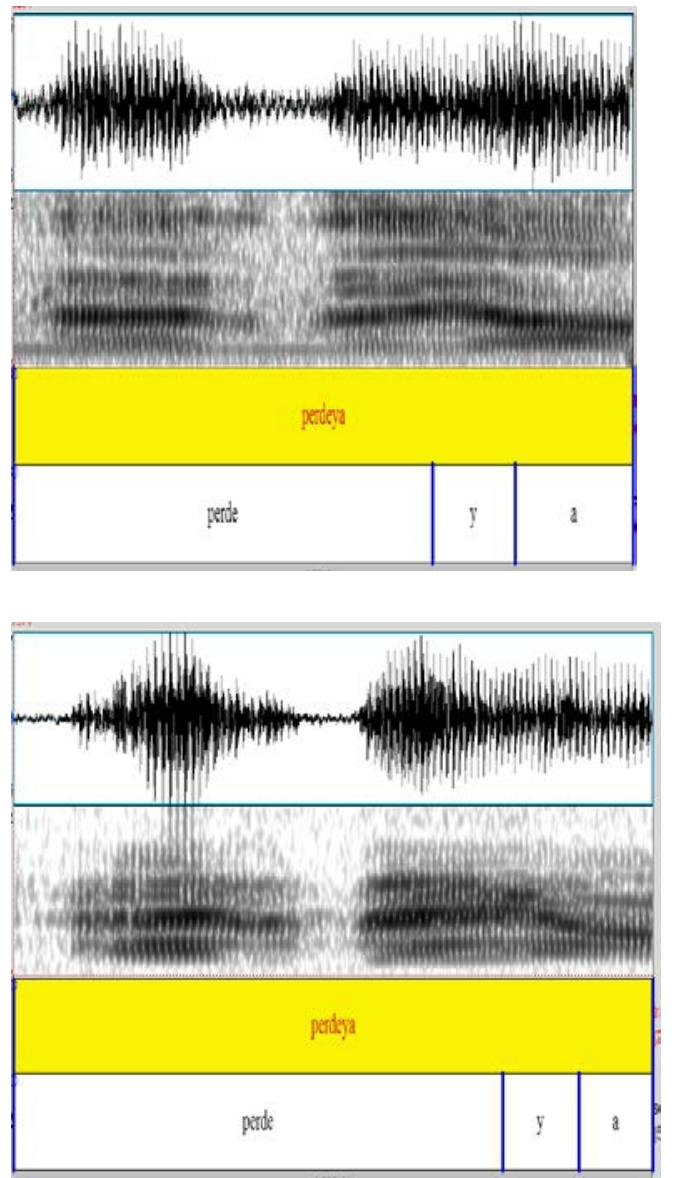
Diarbakir and b) Duhok dialects

This variation in vowel cluster resolution strategy has been referred to before in Hasan (2012). However, she did not specified in which subdialects these variations occur. The study shows that there is variation in the vowel cluster resolution strategy in NK subdialects in word-medial vowel sequence /a/ + /a: a or e:/. In Qamshlo it is solved by vowel deletion, while in Diyarbakir and Duhok both vowel deletion and GI are used.

\section{Hiatus resolution by $/ \mathrm{j} /$ and $/ \mathrm{w} /$ insertion}

Additional dialectal and speaker variations are observed when the vowel sequences $/ \mathrm{u} /+\mathrm{a}$ :, a or $\mathrm{e} / /$ occur in that $/ \mathrm{j} /$ and $/ \mathrm{w} /$ insertions are used to resolve the vowel cluster. In Hewler and Duhok, the speakers inserted /j/ in all these sequences except one speaker inserted $/ \mathrm{w} /$ in his production of the $/ \mathrm{u} /+/ \mathrm{a} /$ sequence in Hewler and one speaker from Duhok inserted $/ \mathrm{w} /$ in the production of the $/ \mathrm{u} /+/ \mathrm{a} / /$. This indicates that $/ \mathrm{w} /$ insertion is a speaker 
variation in these two sub-dialects because it is not repeated constantly by all speakers. However, further verification of this generalisation needs to be done by examining more speakers.

39- $\quad$ saku $+\mathrm{a} \rightarrow$ sakuya / sakuwa (by one speaker in Duhok dialect)

40- $\quad$ saku $+\mathrm{ek} \rightarrow$ sakuyek / sakuwek (by one speaker in Hewler dialect)

41- $\quad$ saku + ên $\rightarrow$ sakuyên

Figure 7 illustrates the variations in the production of the structure $<$ saku $+a>$ by two different speakers from Duhok and Hewler.

a- Duhok

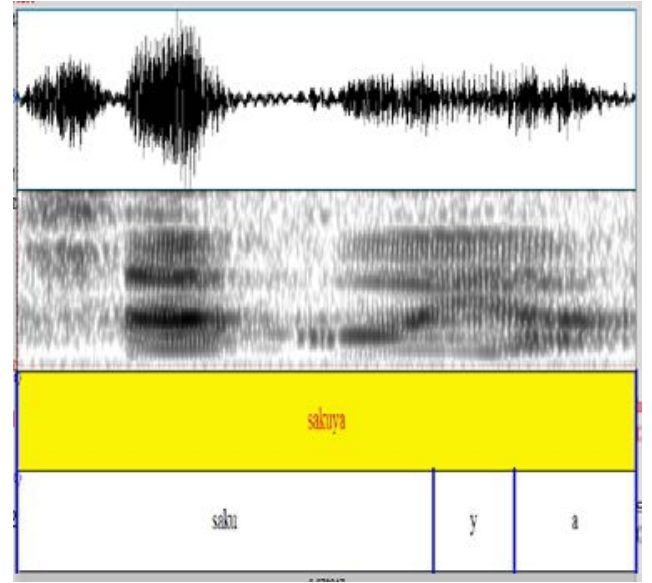

b- Hewler

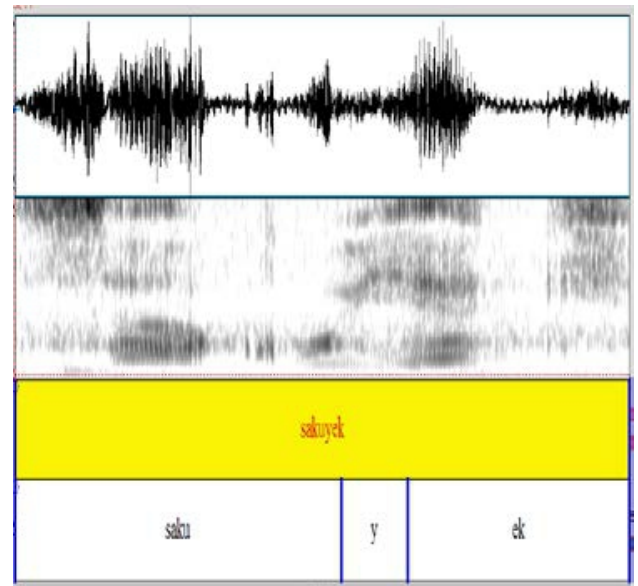

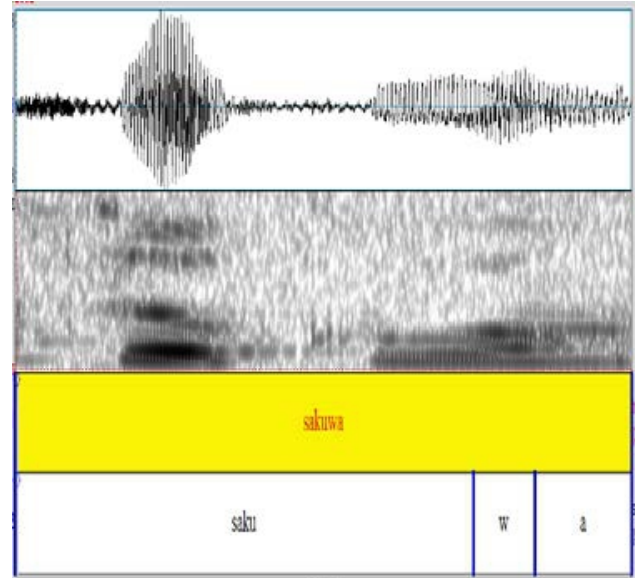
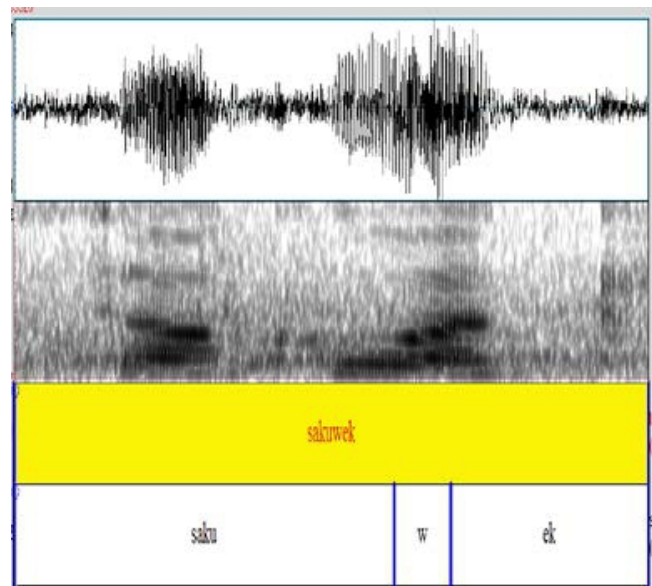

Figure 7: Spectrums of the structure $<$ saku+a $>$ as produced by two different speakers from a) Duhok and b) Hewler dialects

In Diyarbakir and Qamshlo, the speakers produced /j/ and /w/ in their productions of all vowel sequences.

42- saku $+\mathrm{a} \rightarrow$ sakuya / sakuwa

$$
\text { gezu }+ \text { a } \rightarrow \text { gezuya / gezuwa }
$$

43- saku + ek $\rightarrow$ sakuyek / sakuwek 
gezu + ek $\rightarrow$ gezuyek / gezuwek

44- saku + ên $\rightarrow$ sakuyên / sakuwên

gezu + ên $\rightarrow$ gezuyên / gezuwên

Other dialectal and speaker variations are also observed in the sequence of $/ \mathrm{u}: /+/ \mathrm{a}$, e: and $\mathrm{a} /$. In Duhok $/ \mathrm{j} /$ is inserted to resolve the hiatus by all speakers.

45- rû + an $\rightarrow$ rûyan

46- rû + ên $\rightarrow$ rûyên

47- rû + ek $\rightarrow$ rûyek

In Diyarbaker and Hewler, the speakers produce $/ \mathrm{j} /$ to avoid vowel clusters in /u:/+/a: and e:/ sequences. While $/ \mathrm{w} /$ is also used by some speakers in the sequence $/ \mathrm{u}: /+/ \mathrm{a} /$.

48- rû + an $\rightarrow$ rûyan / rûwan

Whereas in Qamshlo only /w/ is inserted in the sequence /u:/+/a: and $\mathrm{e}: /$ by all speakers. Meanwhile, $/ \mathrm{j} /$ and $/ \mathrm{w} /$ are used in the vowel sequences /u:/t/a/.

49- $\quad$ rû $+\mathrm{a} \rightarrow$ rûwa

50- rû + ên $\rightarrow$ rûwên

51- rû + ek $\rightarrow$ rûyek / rûwek

From what is mentioned, it can be concluded that $/ \mathrm{w} /$ insertion after high back vowels $/ \mathrm{u} /$ and $/ \mathrm{u}$ :/ is only a speaker and dialectal variation because it is not repeated constantly by all speakers and in all dialects.

\section{Conclusion}

The study examined a frequent epenthetical process that is used in Kurdish to avoid word-medial vowel clusters, i.e. GI. It takes place wordmedially at root-suffix boundaries. The study showed that word-medial vowel hiatus is always resolved. It is usually resolved by $/ \mathrm{j} /$ insertion. However, other strategies are also observed, namely /w/ insertion and vowel deletion, which seem to occur only in some dialects and in some vowel sequences. $/ \mathrm{w} /$ is inserted only when the back vowels /u or $\mathrm{u}$ :/ are followed by the vowels /a:, a and e:/, but this is not used consistently by all speakers of the dialects. $/ \mathrm{j} /$ is also produced in these vowel sequences in all the dialects examined except Qamshlo in which $/ \mathrm{w} /$ is constantly used in the vowel sequence $/ \mathrm{u}: /+/ \mathrm{a} /$. Vowel deletion is used when the second vowel in a sequence is $/ \mathrm{i} /$. / $/$ / is constantly deleted in all dialects because this vowel is the weakest vowel in Kurdish and it undergoes deletion in most cases (Thackston, 2006; Hasan, 2012). Vowel deletion also occurs in all dialects in the identical vowel sequence /i:/ + i:/ and in Qamshlo in the vowel sequences $/ a /+/ a$; a, and e:/. It is also used in Diyarbakir and Duhok in these vowel sequences, but not constantly because $/ \mathrm{j} /$ is also produced. 
The following table summarises the main dialectal differences in the resolution of vowel clusters in Kurdish.

Table 4: Dialectal variation of GI in Kurdish dialects

\begin{tabular}{|c|c|c|c|c|}
\hline Vowel sequence & Diyarbaker & Duhok & Qamshlo & Hewler \\
\hline $\begin{array}{l}\text { /a:, o/+/a:, a, e:, i:/ } \\
\text { /a, u:/+/i:/ } \\
\text { / i:, e:/+/a: a, e:/ }\end{array}$ & \multicolumn{4}{|c|}{ /j/ insertion } \\
\hline$/ a:, a, o, i:, u: /+/ i /$ & \multicolumn{4}{|c|}{ /i/ vowel deletion } \\
\hline / a / + / a: / & $\begin{array}{c}\text { /a/ vowel } \\
\text { deletion or /j/ } \\
\text { insertion }\end{array}$ & $\begin{array}{l}\text { /a/ vowel } \\
\text { deletion or /j/ } \\
\text { insertion }\end{array}$ & \multirow[t]{3}{*}{$\begin{array}{c}\text { /a/ vowel } \\
\text { deletion }\end{array}$} & \multirow[t]{3}{*}{$\mathrm{j}$} \\
\hline$/ \mathrm{a} /+/ \mathrm{a} /$ & $\begin{array}{c}\text { /a/ vowel } \\
\text { deletion }\end{array}$ & /j/ insertion & & \\
\hline$/ \mathrm{a} /+/ \mathrm{e}: /$ & $\begin{array}{c}\text { /a/ vowel } \\
\text { deletion }\end{array}$ & $\begin{array}{c}\text { /a/ vowel } \\
\text { deletion }\end{array}$ & & \\
\hline$/ \mathrm{u} /+/ \mathrm{a}: /$ & \multirow[t]{3}{*}{$/ \mathrm{j} /$ or $/ \mathrm{w} /$} & $/ \mathrm{j} /$ or $/ \mathrm{w} /$ & \multirow[t]{3}{*}{$/ \mathrm{j} /$ or $/ \mathrm{w} /$} & $\mathrm{j}$ \\
\hline$/ \mathrm{u} /+/ \mathrm{a} /$ & & \multirow[t]{2}{*}{$\mathrm{j}$} & & $/ \mathrm{j} /$ or $/ \mathrm{w} /$ \\
\hline$/ \mathrm{u} /+/ \mathrm{e}: /$ & & & & $\mathrm{j}$ \\
\hline / $\mathrm{i}: /+/ \mathrm{i}: /$ & \multicolumn{4}{|c|}{ /i:/ vowel deletion } \\
\hline$/ \mathrm{u}: /+/ \mathrm{a}: /$ & $\mathrm{j}$ & \multirow[t]{3}{*}{ j } & /j/ or /w/ & $\mathrm{j}$ \\
\hline$/ \mathrm{u}: /+/ \mathrm{a} /$ & /j/ or /w/ & & /w/ & $/ \mathrm{j} /$ or $/ \mathrm{w} /$ \\
\hline$/ \mathrm{u}: /+/ \mathrm{e}: /$ & $\mathrm{j}$ & & $\mathrm{j} / \mathrm{or} / \mathrm{w} /$ & $\mathrm{j}$ \\
\hline
\end{tabular}

The strategy of hiatus resolution, either by GI (whether $\mathrm{j}$ or $\mathrm{w}$ ) or vowel deletion, is accompanied by resyllabification. When a glide is inserted, it acts as the onset of the vowel-initial suffix to avoid onsetless syllables. This satisfies the cross-linguistic onset constraint that syllables must have onsets (Uffmann, 2007; Molczanow, 2008; Blevins, 2008). In other words, Kurdish like other languages has the tendency to have syllables with onsets. Additionally, when vowel deletion occurs, resyllabification occurs in that the remaining consonants act as the coda of the final syllable of the word.

The study concludes that $/ \mathrm{j} /$ insertion is the default strategy to resolve word-medial vowel clusters in Kurdish, the insertion of /w/ or vowel deletion are other strategies which are limited to some dialects and vowel sequences. GI in Kurdish is non-homorganic in that $/ \mathrm{j} /$ is inserted regardless of the vowel quality of the vowels in the sequence, while $/ \mathrm{w} /$ insertion is restricted to some vowel sequences and dialects and it is not repeated constantly by all the speakers of one dialect.

The results of the study provides an understanding of the regional variability in the systematic organisation of phonological patterns. Understanding such variations will lead to a deeper understanding of the phonology of the language. Additionally, the study will help to identify those 
patterns which are the characteristic of the language from those which are only dialectal or contextual variations.

\section{Acknowledgements}

I would like to thank Maraz Ali Ibrahim, a graduate student from English Language Department, University of Zakho for accepting to include her recorded data that used for her graduation project in this study.

\section{References:}

Blevins, J. (2008). Consonant epenthesis: natural and unnatural histories. In Jeff Good (ed.), Language universals and language change. Oxford: Oxford University Press. 79-107.

Boersma, P. \& Weenink, D. (2009). Praat: doing phonetics by computer [Computer program]. Version 5.1.05. Retrieved May 1, 2009, from http://www.praat.org/.

Booij, G. (1996). Cliticisation as prosodic integration: the case of Dutch. The Linguistic Review, 13, pp. 219-242.

Davidson, L., \& Erker, D. (2014). Hiatus resolution in American English: the case against glide insertion. Language, 90(2), 482-514.

Dehghan, M. and Kambuziya, A. K. Z. (2012). A Short Analysis of Insertion in Persian. Theory and Practice in Language Studies, Vol. 2, No. 1, pp. 1423.

Fattah, M. M. (1980). On stress system of Kurdish. In Zanko. pp 177-200.

Harris, J. (2011). Deletion. In Marc van Oostendorp, Marc van Oostendorp, Colin J. Ewen, Elizabeth Hume and Keren Rice's Companion to phonology. Oxford: Wiley.

Hasan, A. M. (2009). Consonant clusters in Kurdish. In Journal of Duhok University, No. 1. pp 1-8.

Hasan, A. M. (2012). Kurdish intonation with reference to English. Unpublished PhD thesis. University of Ulster.

Kurdish Academy of Language (1992). Retrieved 5, 3, 2014, from http://www.kurdishacademy.org/.

Marif, A. H. (1976). Zimanî kurdî libar roşanî fonetîkda (Kurdish language in the light of phonetics). Baghdad: Zanyari Kurdi Press.

McCarus, E. N. (1987). rêzmanî kurdî: fonologî (Kurdish Grammar: Phonology). Translated by Ibrahim Mirani. In Rawşanbiri Niwe, No. 115. pp 149-179.

Mohammed, K. Y. (2009). cêwazî bi karhênana fonîman di kudiya serî u naverastda (variation in the use of phonemes in Northern and Middle dialects of Kurdish). Unpublished MA Thesis. University of Duhok.

Molczanow, J. (2008). Gliding in Russian. Lingua, 118: 1080-1108 
Nevins, A. and Chitoran, I. (2008). Phonological representations and the variable patterning of glides. Lingua, 118:1979-97.

Staroverov, P. (2014). Splitting theory and consonant epenthesis. PhD Thesis. The State University of New Jersey

Thackston, W. M. (2006). Kurmanji Kurdish: A reference grammar with selected readings. Retrieved from http:

//www.fas.harvard.edu/Iranian/kurmanji/kurmanji-complete.pdf/.

Uffmann, Ch. (2007). Intrusive [r] and optimal epenthetic consonants. In Language sciences 29, pp 451-476.

Vaux, B. (2001). Consonant epenthesis and hypercorrection. Ms., Harvard University,

Cambridge, MA.

Ways, G. F. (1984). fonatik (phonetics). Baghdad: Al-Adab Press.

Yasin, M. S. (2006). ziman u rêzmanet kurdî. Dihok: Hawar Press.

Zygis, M. (2009). A perceptual study on glide insertions. ZAS, Berlin. Ms.

Zygis, M. (2010). Typology of consonantal insertions. ZAS papers in linguistics, 52. Pp 111-140. 